\title{
Penguatan Kelembagaan Kelompok Tani Melalui Pelatihan Pengelolaan Administrasi Dalam Mendukung Pencapaian Kegiatan Ekonomi Di Desa Gumantar Kabupaten Lombok Utara
}

\author{
I Wayan Suadnya*, Agus Purbathin Hadi , Dian Lestari Miharja \\ Program Studi Agribisnis, Fakultas Pertanian, Universitas Mataram
}

Kata Kunci:

Penguatan,

kelompok tani,

ekonomi

produktif, North

Lombok

\begin{abstract}
Abstrak: Pendekatan kelompok telah dilaksanakan dan digunakan dalam pembangunan pertanian sejak jaman orde baru. Saat ini terdapat banyak kelompok tani yang tersebar diseluruh desa yang ada di Lombok Utara. Banyak upaya untuk memejukan kelompok tani oleh pemerintah maupun suasta gagal diwujudkan. Hal ini disebabkan oleh berbagai faktor, salah satunya adalah kelengkapan administrasi kelompok. Pengabdian kepada masyarakat ini bertujuan (1) Mengadakan pertemuan untuk melakukan refleksi dan pembahasan tentang pentingnya peran administrasi kelompok dalam melaksanakan kegiatan ekonomi produktif dan kegiatan anggota lainnya. (2) Mengadakan pelatihan tentang penyelenggaraan administrasi kelompok. (3). Menubuhkan wawasan dan visi pengelolaan kelompok dan teknis pengelolaan usaha dimasa yang akan datang melalui diskusi dalam pertemuan kelompok. (4). Mendampingi kelompok dalam penyusunan administrasi kelompok. Untuk mencapai hal tersebut pengabdian dilaksanakan dengan pendekatan andragogi melalui penyuluhan dan pelatihan kelompok. Dari hasil pertemuan dan refleksi bersama 10 ketua kelompok diketahui bahwa anggota dan pengurus kelompok menyadari pentingnya administrasi kelompok dalam menjalin kerjasama dengan pihak lain. Kelompok belum menyelenggarakan admoinistrasi yang baik. Kelompok mau untuk memperbaiki pengelolaan administrasi kelompok dimulai dari perbaikan dan penyempurnaan data kelompok, menyediakan buku tami dan administrasi keuangan kelompok pada tahap awal. Kemudian mereka akan melengkapi kebutuhan administrasi lainnya yang akan disesuaikan dengan kebutuhan kelompok. Dari hasil pelatihan dan pendampingan diketahui ketua kelompok sudah memahami dan mampu membuat buku anggota, buku tamu dan administrasi keuangan kelompok.
\end{abstract}

Korspodensi email: wy.suadnya@gmail.com

\section{PENDAHULUAN}

Pembangunan pertanian di Indonesia sejak program INMAS dan BIMAS diperkenalkan telah menggunakan pendekatan kelompok untuk merealisasikan program programnya. Hampir seluruh instansi lingkup pertanian masih dan terus menggunakan pendekatan kelompok dalam merealisasikan program pemerintah yang ditujukan kepada petani (Suadnya, 1997, Suadnya 2018). Bahkan dalam pendistribusian pupuk bersubsidi dan bantuan input produksi lainnya seperti benih dan obat-obatan dipersyaratkan bahwa petani yang boleh menerima pupuk bersubsidi adalah yang tergabung dalam kelompok tani. Dengan persyaratan ini mau tidak mau petani akhirnya mendaftarkan dirinya menjadi anggota kelompok tani.

Berdasarkan hasil penelitian Suadnya (2017) kelompok tani yang ada belum berfungsi secara maksimal terkesan bahwa kelompok tani hanya aktif ketika akan ada pendistribusian bantuan baik pupuk bersubsidi maupun bantuan lainnya seperti benih dan obat-obatan. 
Olehkarena itu berbagai pihak berusaha untuk meningkatkan peranan kelompok tani melalui berbagai kegiatan termasuk kegiatan ekonomi. Melalui kelompok tani, petani dilatih menggunakan kotoran ternak untuk pupuk organik (Suadnya,2015). Melalui kelompok tani petani dilatih untuk melakukan kegiatan ekonomi produktif dan peningkatan kemampuan berproduksi dalam usahataninya.

Kenyataannya sekarang usaha-usaha itu belum mampu meningkatkan peran dan kemampuan kelompok dalam mengelola usaha ekonomi produktif yang telah diberikan dan disuluhkan oleh para pihak. Disamping itu usaha dan upaya para penyuluh serta mereka yang menaruh perhatian terhadap masalah petani untuk membantu petani mengakses modal dan input pertanian dari stakeholder juga belum mampu direalisasikan. Hasil penelitian Suadnya 2017 menunjukkan bahwa kurangnya kesadaran petani untuk berkelompok, pengelolaan kelompok terutama administrasi kelompok dan kemampuan managerial pengurus disinyalir sebagai penyebab lambatnya perkembangan kelompok tersebut. Oleh karena itu pengabdian ini dimaksudkan untuk melakukan penguatan kelembagaan kelompok tani agar mereka mampu untuk melaksanakan kegiatan ekonomi produktif yang diintroduksi oleh para pihak. Kegiatan ini khususnya ditujukan untuk meningkatkan kemampuan penyelenggaraan administrasi kelompok, sehingga kelompok memiliki data dan informasi tertulis tentang kelompoknya yang sering dijadikan persyaratan oleh mitra kelompok dalam menjalin kerjasama.

Keadaan seperti yang diuraikan di atas juga ditemukan di Desa Gumantar yang merupakan salah satu Desa di Kecamatan Kayangan Kabupaten Lombok Utara, dimana sebagian penduduknya bekerja disektor pertanian. Sejak tahun 2015 sampai tahun 2018, pengusul melakukan kegiatan kemitran dalam rangka membantu petani mengakses sumber permodalan yaitu Bank dan sumber input produksi yaitu private sektor seperti PT Syngenta, agar petni mampu melaksanakan usahataninya dengan baik dan tepat guna. Namun dalam prosesnya pengusul menemukan bahwa kelembagaan kelompok tani belum bisa berfungsi dengan baik karena kesadaran anggota yang masih kurang, kemampuan menegerial pengurus masih kurang dan kemampuan administrasi kelompok yang sangat kurang. Pengabdian kepada masyarakat ini akan dilakukan untuk mengatasi salah satu masalah yang dihadapi kelompok tani di Desa Gumantar yaitu masalah administrasi kelompok. Tujuan pengabdian pada masyarakat di Desa Gumantar adalah untuk meningkatkan kemampuan administrasi kelompok sehingga kelompok memiliki buku administrasi kelompok dan bisa menyelenggarakan administrasi kelompok secara baik.

\section{METODE KEGIATAN}

Untuk mencapai tujuan pengabdian tersebut di atas, Kegiatan yang dilaksanakan dalam pengabdian pada masyarakat adalah pelatihan dan pendampingan kepada pengurus kelompok dalam menyusun dan menyelenggarakan administrasi kelompok yang sesuai dengan kebutuhan kelompok. Pelatihan dan pendampingan yang dilaksanakan menggunakan pendekatan pendidikan orang dewasa (Andragogy) untuk meningkatkan kapasitas dan kemampuan pengurus kelompok. Prinsif-prinsif action learning digunakan sehingga proses belajar dapat direncanakan dengan baik, kegiatan pelatihan terlaksana secara terstruktur dan 
sesuai kebutuhan kelompok, hasilnya dapat diobservasi serta dilakukan refleksi terhadap hasil kegiatan sehingga dapat dilakukan perbaikan (replan) untuk perbaikan selanjutnya. Proses pelaksanaan kegiatan dengan menggunakan prinsif action learning disajikan pada gambar 3 berikut ini.

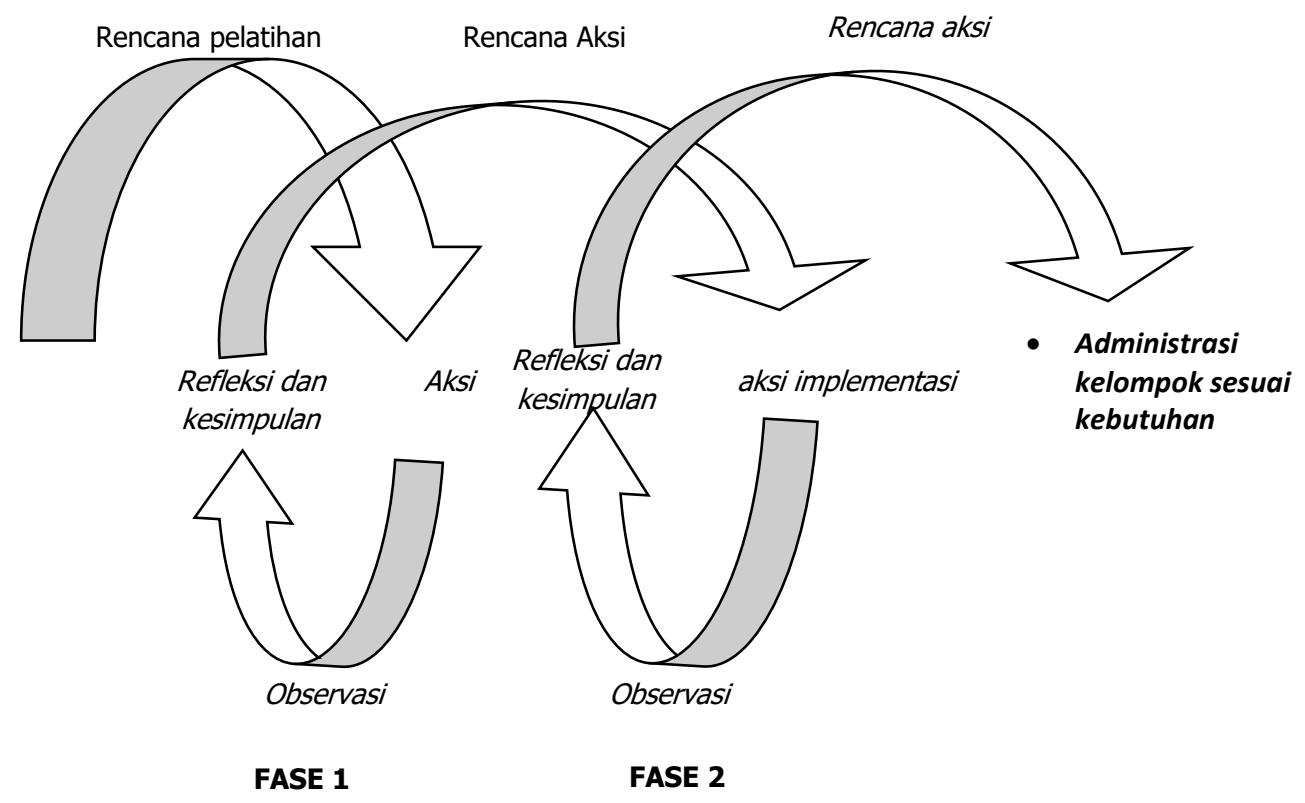

Gambar 1. Action learning principle (di adaptasi dari Kolb, 1984)

Dengan pendekatan andragogy (Kindervatter, 1979) semua proses pelatihan didesain menggunakan action learning cycle. Dengan demikian partisipasi dan peran pengurus dalam pelatihan menjadi lebih besar sedangkan tim pengabdian pada Masyarakat Universitas Mataram menjadi fasilitator dalam kegiatan ini. Untuk mendampingi kelompok dalam kegiatannya dibantu oleh mahasiswa KKN yang sedang bertugas di Desa Gumantar. Pengabdian kepada masyarakat ini diselenggarakan tanggal 7-15 Agustus 2019 di Gumantar Kabupaten Lombok Utara. Tahap-tahap kegiatannya adalah sebagai berikut:

1. Pada tahap pra pelatihan, Ketua ketua kelompok tani di undang untuk datang dan berkumpul di rumah salah satu ketua kelompok tani. Tujuannya adalah untuk menyepakati jadwal dan materi penyuluhan yang direncanakan.

2. Hari pertama pelatihan, pengurus kelompok tani diundang untuk menghadiri pertemuan yang sudah disepakati dalam rangka refleksi dan pemahaman tentang kelompok tani mereka khususnya yang terkait dengan administrasi dan pembukuan kelompok. Materi penyuluhan yang disampaikan meliputi kesadaran berkelompok, visi dan misi kelompok, manajemen kelompok dan administrasi kelompok. Metode yang digunakan adalah diskusi dan presentasi

3. Selanjutnya, hari kedua dilakukan Pelatihan penyelenggaraan administrasi kelompok serta pembuatan buku administrasi kelompok. Peserta dilatih membuat dan menyusun buku anggota kelompok. Peserta dibagi ke dalam 4 kelompok kerja. Masing-masing kelompok diberikan kesempatan untuk membuat dan menyusun buku anggota sesuai dengan keadaan anggotanya masing-masing. Dari hasil kerja kelompok, kemudian dilakukan pleno untuk membahas hasil kerja kelompok. 
4. Berdasarkan hasil refleksi dari kerja kelompok kemudian dilakukan pemaparan untuk menyempurnakan pemahaman ketua kelompok mengenai pembukuan dan administrasi kelompok. Dilakukan pemaparan tentang buku anggota dan cara membuatnya agar sesuai dengan data dan fakta keadaan anggota masing-masing kelompok. Demikian juga halnya dengan buku keuangan kelompok dan buku tamu.

5. Pada akhir sesi pelatihan kepada ketua kelompok diberikan bantuan buku untuk membuat administrasi kelompok yang meliputi buku anggota, buku administrasi keuangan dan buku tamu. Para ketua kelompok juga diberikan format penyusunan masing-masing buku yang dimaksud.

6. Selanjutnya dilakukan kunjungan untuk memonitoring dan pendampingan, apakah administrasi kelompok yang diajarkan sudah dibuat oleh pengurus.

\section{HASIL DAN PEMBAHASAN}

Kegiatan pelaksanaan pengabdian kepada masyarakat yang bertujuan untuk mewujudkan taget luaran: (1) Meningkatnya pengetahuan, perubahan sikap, dan ketrampilan dalam menyelenggarakan tertib administrasi dan pembukuan kelompoktani dan teresedianya buku administrasi kelompok telah dilaksanakan di Desa Gumantar mulai tanggal 7 - 15 Agustus 2019. Serangkaian kegiatan telah dilaksanakan sesuai dengan langkah-langkah yang disajikan pada bagian metode pelaksanaan.

Namun sebelum pelaksanaan kegiatan pengabdian dilaksanakan terlebih dahulu dilaksanakan kegiatan penjajakan dan pertemuan dengan calon peserta untuk membahas tentang jadwal pelaksanaan pengabdian. Kegiatan pengabdian pada masyarakat ini diawali dengan melakukan kunjungan kepada kelompok tani di Desa Gumantar pada tanggal 3 Agustus 2019. Pada kunjungan ini Tim peneliti bertemu dengan 2 orang ketua kelompok dan menyepakati bahwa pelatihan administrasi kelompok akan dilaksanakan dari tanggal 7-15 Agustus 2019esa Gumantar. Kedua orang ini selanjutnya menjadi penghubung untuk mengundang 20 orang pengurus kelompok tani dari 10 kelompok yang ada di Desa Gumantar.

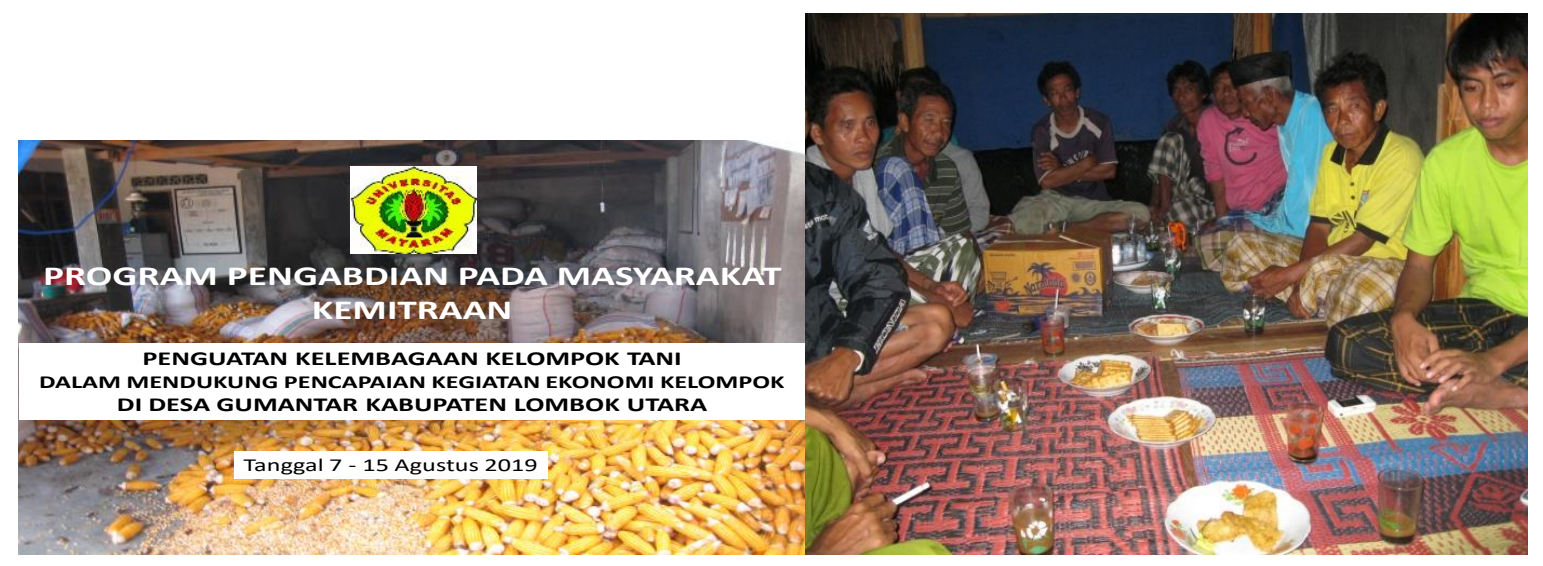

Spanduk

Pertemuan Pertama membangun Kesepakatan

Kegiatan tanggal 7 Agustus direncanakan untuk menyampaikan materi kesadaran berkelompok, visi dan misi kelompok. Pertemuan kedua disepakati dilaksanakan pada 
tanggal 8 Agustus 2019 dengan materi Pengembangan administrasi kelompok. Pertemuan ke tiga disepakati pada tanggal 15 Agustus 2019 dengan tujuan untuk mendampingi penyusunan administarasi kelompok.

Kegiatan pengabdian ini dilaksanakan dengan materi yang disampaikan oleh tim pengabdian Universitas Mataram yaitu Ir. I Wayan Suadnya, M.Agr.Sc., Ph.D.; DR. Ir. Agus Purbathin Hadi, M.Si.; Dian Lestari Miharja, S.P. MA. Adapun materi yang disampaikan meliputi Pemahaman dan pentingnya petani berkelompok.

Dari hasil refleksi yang dilakukan pada sesi pelatihan hari pertama dapat diketahui bahwa pengurus kelompok belum memiliki visi dan misi yang jelas dalam mengembangkan kelompok. Disamping itu, pengurus kelompok juga mengungkapkan bahwa administrasi dan pembukuan kelompok belum baik, kelompok hanya memiliki buku anggota saja. Informasi yang terkandung dalam buku anggota masih hanya terbatas pada nama anggota, alamat dan keterangan yang belum terisi dengan baik. Kondisi kelomok seperti ini sesuai dengan temuan suadnya (1997) suadnya (2006). Berdasarkan hasil diskusi yang dilaksanakan pada kegiatan pengabdian tersebut di atas, pengurus kelompok berharap dapat diberikan pemahaman yang lebih baik mengenai kelompok dan khususnya administrasi dan pembukuan kelompok.

Berdasarkan hasil studi pendahuluan dan refleksi pengurus kelompok materi mengenai visi dan misi kelompok serta pentingnya pengembangan kelompok telah diajarkan kepada pengurus kelompok yang nantinya diharapkan dapat ditindak lanjuti ditingkat kelompok dalam rangka meningkatkan kesadaran anggota untuk berkelompok dan penyusunan visi dan misi serta tujuan kelompok. Berdasarkan hasil evaluasi yang dilakukan oleh tim diketahui bahwa pengurus kelompok sudah memahami bagaimana caranya menyusun visi dan misi serta tujuan kelompok. Namun tim masih akan melakukan pendampingan jika dalam waktu dekat ada kelompok yang melakukan kegiatan tersebut. Pendampingan merupakan hal fundamental kalau hasil pelatihan diharapkan untuk diterapkan oleh peserta (Bembridge, 1991).

Setelah mengikuti pelatihan pembuatan buku anggota, buku tamu dan buku kas kelompok serta buku-buku pembukuan kelompok lainnya, pengurus kelompok menyatakan akan memperbaiki pembukuan kelompok. Namun pengurus kelompok menyatakan mereka akan fokus pada perbaikan buku anggota yang mereka rasakan mendesak untuk diperbaiki dan memerlukan partisipasi anggota untuk mengisinya. Buku anggota kelompok memang sangat diperlukan oleh sebuah kelompok agar kelompok mempunyai data lengkap tentang anggotanya. Kondisi buku anggota saat ini masih sangat memperihatinkan, karena dibuat dengan sangat sederhana dan terkesan seadanya. Data dan informasi yang ditampilkan dalam buku anggota juga sangat terbatas sehingga sangat tidak representatif jika digunakan untuk menyusun rencana definitif kebutuhan kelompok (RDKK) maupun kebutuhan untuk melakukan kerjasama dengan pihak luar.

Saat laporan ini disusun pengurus kelompok sedang melakukan pendataan ulang terhadap anggotanya dengan menggunakan format yang sudah disiapkan sehingga buku anggota diharapkan mampu menyajikan data yang dibutuhkan untuk kepentingan kelompok dan kerjasama dengan pihak lain. Kegiatan ini memerlukan waktu karena memerlukan partisipasi anggota dan kesediaan pengurus untuk keliling menemui anggotanya untuk melakukan pendataan. Dalam proses ini, pengurus juga menemui beberapa kendala 
diantaranya adalah pendataan luas lahan, karena masih ada anggota tidak secara jujur melaporkan luas lahan yang dimiliki. Disamping itu untuk mengunjungi anggota satu persatu juga memerlukan waktu dan tenaga, karena sulit untuk mengharapkan anggota yang mendatangi ketua untuk memberikan data dan informasi kepada pengurus. Hal ini terjadi karena tidak semua anggota kelompok mempunyai alat komunikasi seperti handphone (HP).

Khusus pembukuan keuangan kelompok, selama ini kelompok memang belum mempunyai kas yang cukup banyak karena memang kelompok tidak ada melakukan kegiatan yang menyangkut keuangan kecuali ada kegiatan tertentu dimana anggota harus mengumpulkan uang untuk keperluan kelompok tertentu. Untuk membukukan keuangan dalam kegiatan tersebut biasanya pengurus kelompom hanya menggunakan catatan seadanya karena mereka beranggapan bahwa uang tersebut akan habis setelah kegiatan dilaksanakan. Oleh karena itu maka kelompok tidak memiliki buku pencatatan keuangan kelompok. Pelatihan dan pembuatan buku kas kelompok dilakukan dan direspon positif oleh pengurus kelompok karena sering ketika kegiatan kelompok yang memerlukan uang dan pencatatan keuangan, pengurus tidak memiliki buku untuk mencatat sisa uang, dan data tentang anggota yang sudah menyetor ataupun belum iuran kepada pengurus. Sering pengurus tekor karena pencatatan tidak akurat. Dengan pelatihan ini pengurus merasa sangat terbantu dan akan menggunakan buku kas tersebut untuk mencatat keuangan kelompok. Sampai saat laporan ini disusun belum ada pengurus kelompok yang dimonitor melakukan kegiatan pembukuan keuangan dengan alasan belum ada kegiatan yang memerlukan pencatatan keuangan.

Sedangkan untuk buku tamu pengurus sudah menggunakannya, karena tim datang berkunjung kekelompok dalam rangka memonitor hasil kegiatan pengabdian telah disuguhkan buku tamu untuk diisi. Dengan demikian, sebagian kecil dari kegiatan pengabdian yang telah dilaksanakan ditindaklanjuti oleh sasaran pengabdian kepada masyarakat. Hal ini dapat dimaklumi karena memang kegiatan pengabdian kepada masyarakat memerlukan waktu yang cukup panjang dan kegiatan yang berkesinambungan untuk mewujudkan hasilnya. Penulis meyakini bahwa apabila kegiatan pengabdian seperti yang dilakukan, hanya bersifat pengabdian temporer sewaktu-waktu dengan durasi satu minggu maka dapat diprediksi bahwa hasilnya akan sangat kecil. Hal ini terjadi karena proses untuk mewujudkan hasil dari pengabdian yang penulis lakukan memerlukan waktu yang cukup panjang untuk mewujudkannya karena keberhasilannya juga tergantung partisipasi anggota kelompok dan keaktifan pengurus kelompok. Khusus untuk keaktifan pengusur kelompok sebetulnya dapat diatasi dengan melakukan monitoring dan pendampingan. Tetapi karena untuk melakukan pendampingan dan monitoring memerlukan waktu yang cukup dan dana yang banyak maka, tim tidak dapat melakukannya secara terus menerus dalam jangkan panjang, oleh karena itu keberhasilan pengabdian yang dilakukan mungkin akan sangat kecil.

Berdasarkan hasil monitoring dan hasil analisis dari kegiatan pengabdian yang telah dilaksanakan maka pengabdian kepada masyarakat yang diusulkan dan dapat didanai oleh Lembaga Penelitian dan Pengabdian kepada Masyarakat (LPPM) hendaknya mempunyai durasi waktu yang panjang dan dengan dana yang memadai sehingga proses pelaksanaan kegiatan pengabdian dapat dilaksanakan dengan melakukan pendampingan serta monitoring dalam jangka waktu yang panjang sehingga hasilnya bisa menjadi lebih baik. 


\section{KESIMPULAN DAN SARAN}

Dari hasil pembahasan di atas dapat disimpulkan bahwa pelaksanaan kegiatan pengabdian kepada masyarakat yag telah dilaksanakan berjalan dengan baik dan mendapat sampbutan yang baik dari pengurus kelompok. Pengurus kelompok melalui refleksi yang dilakukan telah berhasil mengidentifikasi kekurangan kelompok dan mau untuk memperbaiki, sesuai dengan hasil pelatihan yang telah dilaksanakan. Namun dalam melaksanakan hasil pelatihan pembukuan kelompok masih ditemukan berbagai kendala diantaranya adalah realisasi hasil pelatihan membutuhkan waktu dan perlu pendampingan yang berkesinambungan. Masih ada anggota yang tidak jujur dalam memberikan data dan informasi serta kegiatan pembukuan keuangan sampai saat laporan pengabdian dibuat belum ada, sehingga belum ada hasilnya. Perlu pendampingan dan monitoring yang berkesinambungan untuk merealisasikan hasil pengabdian masyarakat yang dilaksanakan. Perlu waktu yang lebih panjang untuk melaksanakan pengabdian kepada masyarakat dengan dana yang lebih besar.

Disarankan agar pengabdian masyarakat dilaksanakan dalam kurun waktu yang panjang dan berkesinambungan serta dana yang lebih besar untuk memperoleh hasil yang lebih baik.

\section{DAFTAR PUSTAKA}

Bembridge, T. 1991, Practical Guidelines For Agricultural Extension Workers, A Field Manual, Development Bank of Southern Africa, Halfway House.

Direktorat Jenderal Peternakan, Departement Pertanian, 2008. Kebijakan dan Strategi Pengembangan Ternak. Makalah Disajikan pada Seminar Nasional Teknologi Peternakan dan Veterinary di Cisarua, Bogor, 10-11 November 2008.

Freire, P. 1982, Creating Alternative Research Methods, in Creating Knowledge: A Monopoly? Participatory Research in Development, Participatory Research Series No. 1, pp. 29-37.

Kindervatter, S. 1979. Non-formal Education as an Empowering Process With Case Studies from Indonesia and Thailand, Center for International Education, University of Massachusetts, Massachusetts.

Kolb, D.A. 1984, Experiential Learning: Experience as A Source of Learning and Development, Prentice Hall, New York.

Suadnya, I.W., Muktasam, Puspadi. K., Nuga, P. 2010. Understanding Community's Knowledge on Climate Changes and Their Adaptation Strategies: In Searching for Effective Dissemination of Climate Change Information (2010-2014)

Suadnya, 1997. Faktor yang Mempengaruhi kKesuksesan Kelompok. Tesis S2. The University of Queensland.

Suadnya, I.W. 2010. Measure to Cope and Dealing with Impact of Climate Change in West Nusa tenggara". A paper presented in the Seminar "Penyiapan Masyarakat Adat Menghadapi Mitigasi dan Adaptasi Perubahan Iklim di Lombok Utara” 27 June 2010.

Suadnya, I. W. 2010. Coordination and Strategy development for Mitigation and Adaptation of Climate Change in West Nusa Tenggara. A paper presented at Coordination 
Workshop of Climate Change and Ozon Layer Protection hosted by Badan Lingkungan Hidup dan Penelitian Provinsi Nusa Tenggara Barat, 25 February 2010 Zimmerman, M. A. 1995, Psychological Empowerment: Issues and Illustration, American Journal of Community Psychology, vol. 23, pp. 581-99. 